Article

\title{
Evaluating Appointment of Division Managers Using Fuzzy Multiple Attribute Decision Making
}

\author{
Hsu-Lin Chen *, Yi-Chung Hu $@$ and Ming-Yen Lee \\ Department of Business Administration, Chung Yuan Christian University, Taoyuan 32023, Taiwan; \\ ychu@cycu.edu.tw (Y.-C.H.); Mingyen@cycu.edu.tw (M.-Y.L.) \\ * Correspondence: lingo@cycu.org.tw
}

Citation: Chen, H.-L.; Hu, Y.-C.; Lee, M.-Y. Evaluating Appointment of Division Managers Using Fuzzy Multiple Attribute Decision Making. Mathematics 2021, 9, 2417. https:// doi.org/10.3390/math9192417

Academic Editor: Tin-Chih Toly Chen

Received: 8 August 2021

Accepted: 18 September 2021

Published: 28 September 2021

Publisher's Note: MDPI stays neutral with regard to jurisdictional claims in published maps and institutional affiliations.

Copyright: (c) 2021 by the authors. Licensee MDPI, Basel, Switzerland. This article is an open access article distributed under the terms and conditions of the Creative Commons Attribution (CC BY) license (https:/ / creativecommons.org/licenses/by/ $4.0 /)$.

\begin{abstract}
Subsidiaries typically start out as a company division. As the company expands its product lines, the regions it operates in, or the customers it serves, the company is likely to combine the related research and development, procurement, production, and sales departments into a relatively discrete organizational structure. As such, the head of the division is often of equal importance as the company president. In particular, when the product has a competitive advantage, the head of the division has more authority in the company's future operational planning. Thus, when a company has a multidivisional organizational structure, the heads of those divisions typically have considerable responsibilities. In this study, literature data were combined with a fuzzy Delphi expert questionnaire survey to determine the constructs and criteria for assessing candidates for division manager. Subsequently, the fuzzy decision-making trial and evaluation laboratory (DEMATEL) and the fuzzy DEMATEL-based analytic network process were used to identify the causal relationships between criteria and their weights, and the fuzzy technique for the order of preference by similarity to ideal solution was used to rank the solutions to approximate the company's optimal candidate for division manager and provide the ideal decision-making solutions, which may offer companies with the reference of selecting the senior executives.
\end{abstract}

Keywords: division manager; fuzzy Delphi; DEMATEL; ANP; fuzzy TOPSIS

\section{Introduction}

A multidivisional organizational structure is generally formed to meet the needs of a company expanding its scale and diversifying its businesses. This type of organizational structure involves centralized control and decentralized management: a decentralized operational organization under coordinated control. Mintzberg [1] proposed five types of organizational structures: simple structure, machine bureaucracy, professional bureaucracy, divisional structure, and adhocracy. A divisional structure is based on centralized control and decentralized management, with each division accepting profit-sharing responsibilities; these divisions can determine their own products and markets and independently manage the business activities of their departments. However, the operations of each division must be reported to the company's top management, which assesses each division on the basis of their business profits and losses. Each division, having its own functional structure, strives to operate independently and be responsible for its own profits and losses. Yin [2] argued that the Formosa Plastics Group treats each division as a profit center in charge of its own profits and losses; in other words, when each division is considered a business unit, under a divisional structure, market opportunities are combined with the internal structure of the company to form a model in which each division has its own separate accounting and independent operations.

\subsection{Research Background and Motivations}

Organizations must continually pursue profits to maintain long-term business operations. However, in this age of meager profits, business operations have become even 
more stringent. As such, if a company decides to diversify its products, it must also plan to adopt a divisional structure. Chandler [3] proposed that a multidivisional form (Mform) is the optimal organizational structure for diversified companies, because senior executives with diverse experience are more familiar with their division's business, the performance of M-form depends considerably on the top managers, and the traits of a supervisor affects team performance. These traits are widely considered by pedagogues to include motivation, skills, and a self-concept or social role, as well as the use of this knowledge to generate higher and more effective job performance and become a key factor affecting the company's operations. These traits are the competencies that a professional leader should possess. Page et al. [4] also maintained that the professional competencies in an organization that enable effective or high performance were the skills, capabilities, and personality traits that managers should have. Therefore, this study is a discussion of how succession planning based on the competences of a division manager enables a company to appoint division managers that are suited to each division's business. This discussion can then be distilled into guidelines on candidate appointments for companies pursuing a multidivisional structure to enhance their competitive advantages in their business operations.

\subsection{Research Purpose}

According to the stated research background and motivations, the purpose of this study is (1) to determine the criteria for appointing division managers by using theoretical discussions, literature collection, and expert opinions, and (2) to determine the key factors and weights among the appointment criteria. Subsequently, these criteria are ranked according to their priority in the appointment of specific division (research and development, production, business, and administration) managers to form a reference for companies in the hiring process.

\section{Literature References}

This study attempts to establish the major criteria for appointing division managers on the basis of senior executive traits, professional development, professional skills and abilities, and organizational design. These criteria then form the research framework.

\subsection{Divisional Organizations}

In a divisional organization, budgets are set according to hierarchical management and hierarchical accounting, with profit centers bearing the responsibility for their own profits and losses. Some divisions are determined by region or profit types. The division and its plants are in charge of product research and development (R\&D) and design, material procurement, cost accounting, production, and product sales, whereas the head office is responsible for final human resource decisions and overseeing the budgets. OrdonezPonce and Clarke [5] explained that in an M-form organization, all functional divisions are strategic partners. Wen [6] argued that when addressing changes to single functional organizations caused by uncertainty in a complex environment, because each division can manage its own functional departments, a divisional organization can circumvent the difficulties involved in communication between functional organizations; in dynamic markets, companies also guarantee the compatibility of its organization and product designs with the environment in accordance with its organizational form [7]. Kang [8] revealed that companies with a multidivisional structure can more easily adapt to external environment changes and avoid the shortcomings of a centralized design, as excessive centralization can lower the quality and speed of decisions, as well as the organization's ability to respond to markets. Duncan [9] argued that divisions in an organization can integrate many functions within a company, resulting in smoother and clearer communication between divisions. A multidivisional structure is more suited to differentiated needs that arise from the diversification of product regions and customers and can thus improve the organization's performance. M-forms are the predecessors of subsidiary companies because they already 
have sufficient resources for handling environmental complexities. As such, when faced with high market uncertainty, when products are subject to specification transformations from new technologies, an M-form can immediately adjust its business directions according to the situation without waiting for the head office to decide [10]; as a result, the approach of division managers in delegation, decisions, and operational management has gradually shifted toward independent corporate governance. A summary of the comparison of strategic business units (SBU) and corporate core competence conducted by Hamel and Prahalad [11] is presented in Table 1. The M-form plays a key role in a company's organizational planning; when a company gradually expands its product lines and regions, its functionality allows the organization to respond to various environmental changes. Therefore, in terms of the appointment of division managers, the literature on organizational structures highlights the importance of a division manager in the company and clarifies the traits of the role in question. Daft [12], in Organization Theory and Design, stated that an increasingly complex organization is inclined to transform from a functional department into the $\mathrm{M}$-form structure, with each division including its own business, $R \& D$, production, and administrative departments. Figure 1 provides an organizational chart.

Table 1. Two concepts of the corporation: SBU or core competence.

\begin{tabular}{|c|c|c|}
\hline & Division & Core Competence \\
\hline Basis for competition & Competitiveness of today's products & Interfirm competition to build competencies \\
\hline Corporate structure & $\begin{array}{c}\text { Portfolio of businesses related in } \\
\text { product-market terms }\end{array}$ & $\begin{array}{c}\text { Portfolio of competencies, core products, } \\
\text { and businesses }\end{array}$ \\
\hline Status of the business unit & $\begin{array}{c}\text { Autonomy is sacrosanct; the SBU "owns" all } \\
\text { resources other than cash }\end{array}$ & $\begin{array}{c}\text { SBU is a potential reservoir of } \\
\text { core competencies }\end{array}$ \\
\hline Resource allocation & $\begin{array}{l}\text { Discrete businesses are the unit of analysis; } \\
\text { capital is allocated business by business }\end{array}$ & $\begin{array}{c}\text { Businesses and competencies are the unit of } \\
\text { analysis; top management allocates capital } \\
\text { and talent }\end{array}$ \\
\hline Value added of top management & $\begin{array}{l}\text { Optimizing corporate returns through capital } \\
\text { allocation trade-offs among businesses }\end{array}$ & $\begin{array}{l}\text { Enunciating strategic architecture and } \\
\text { building competencies to secure the future }\end{array}$ \\
\hline
\end{tabular}

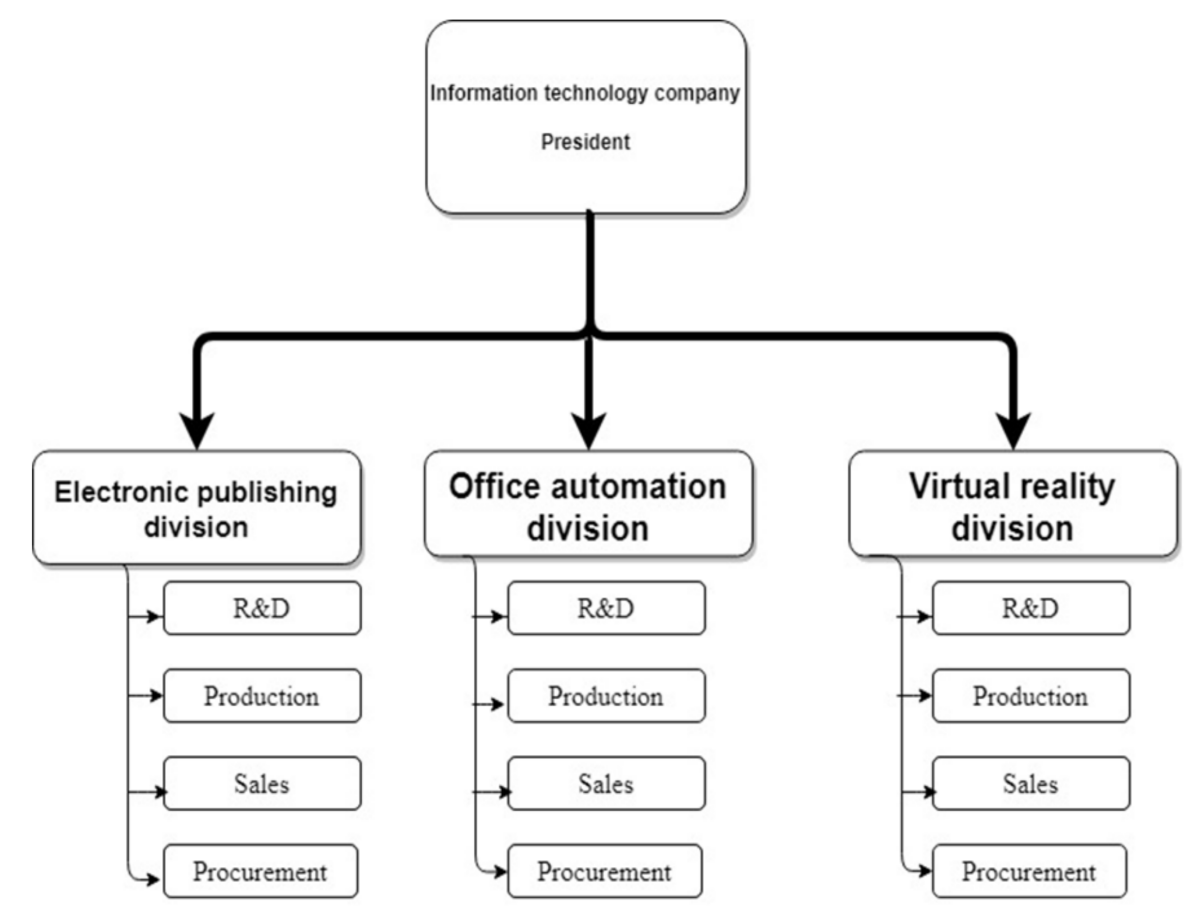

Figure 1. Chart of divisional organizations. 


\subsection{Successor Traits and Abilities}

The succession position being discussed in this study is division manager. Rothwell [13] held that the successors should not be limited to leadership or managerial levels; instead, candidates of all types and levels should be considered. In a large company, a division manager has a role similar to chief operating officer (COO), which carries great responsibilities, but its traits and competencies have not been studied much. A senior executive's management beliefs determine the organizational change and its direction [14], and in a company's succession, the $\mathrm{COO}$ is typically the management knowledge center regarding the successors for the chief executive officer or president [15]. Lessem [16] held that a successor must have competencies that include the ability to influence, the ability to learn, the ability to create, and the attitude to work. Tu [17] also argued that the traits of an exemplary successor include having personal charisma, leadership skills, and a learning ability as well as employing the right person for the right job. The main functions of a division manager involve operational governance, $R \& D$ innovation, production control, and technical improvements of the products that they oversee, requiring a diversified conceptual competence which is reflected in the traits of a successor. The function of a division manager also includes organizing information from outside experts on the practices of senior executives. This is mainly because consultancies can provide companies with independent and objective consulting services and experts can assist organizations by proposing the analysis of and solution to management problems at the appropriate time. These suggestions enable customers to implement immediate response measures [18]. A summary of expert opinions on managerial qualities is presented in Table 2; Table 3 is an overview of the findings of Ivancevich et al. [19], as compiled by Hsiao [20].

Table 2. Managerial qualities.

\begin{tabular}{|c|c|}
\hline Managerial Qualities & References \\
\hline \multicolumn{2}{|l|}{ 1. Positive leadership } \\
\hline \multicolumn{2}{|l|}{ 2. Curiosity and creativity } \\
\hline 3. Practical and careful planning & Guo [21] \\
\hline \multicolumn{2}{|l|}{ 4. High-level and self-disciplined execution skills } \\
\hline \multicolumn{2}{|l|}{ 5. Science-based decision-making abilities } \\
\hline \multicolumn{2}{|l|}{ 1. Must be able to set objectives } \\
\hline \multicolumn{2}{|l|}{ 2. Seek to integrate the organization as a whole } \\
\hline \multirow{2}{*}{\multicolumn{2}{|c|}{$\begin{array}{l}\text { 3. Must be able to encourage and communicate } \\
\text { 4. Make assessments when appropriate }\end{array}$}} \\
\hline & \\
\hline \multicolumn{2}{|l|}{ 5. Nurture talent, including their own } \\
\hline \multicolumn{2}{|l|}{ 1. Must be perceptive } \\
\hline \multicolumn{2}{|c|}{ 2. Calm, humble, focused, and persistent; able to learn from mistakes } \\
\hline \multicolumn{2}{|c|}{ 3. Organized and analytical thinking } \\
\hline \multicolumn{2}{|c|}{ 4. Able to make accurate judgments on the basis of independent thinking } \\
\hline 5. A generalist that asks for details & Bolton [23] \\
\hline 6. Determination to win & Book Republic \\
\hline \multicolumn{2}{|l|}{ 7. Willing to adopt different strategies } \\
\hline \multicolumn{2}{|l|}{ 8. Self-understanding } \\
\hline \multicolumn{2}{|l|}{ 9. Sufficient experience } \\
\hline \multirow{2}{*}{\multicolumn{2}{|c|}{ 10. Integrity }} \\
\hline 1. Integrity above all & \\
\hline \multirow{2}{*}{\multicolumn{2}{|c|}{$\begin{array}{l}\text { 2. Sense of responsibility that prioritizes the company } \\
\text { 3. Self-confidence and acceptance of challenges }\end{array}$}} \\
\hline \multirow{2}{*}{\multicolumn{2}{|c|}{ 3. Self-confidence and acceptance of challenges }} \\
\hline 4. Active enthusiasm and the courage to pursue change & \\
\hline 5. Prospective insights; looking to the future & Management Magazine \\
\hline \multicolumn{2}{|l|}{ 6. Innovating and challenging old customs } \\
\hline \multicolumn{2}{|l|}{ 7. Pursuit of greater accomplishments } \\
\hline 8. Resolution to make value-based judgments & \\
\hline
\end{tabular}


Table 3. Senior executive traits.

\begin{tabular}{|c|c|c|c|c|}
\hline \multirow{2}{*}{$\begin{array}{c}\text { Type } \\
\text { Physiological traits }\end{array}$} & \multicolumn{4}{|c|}{ Factors } \\
\hline & Age & Appearance & Height & Weight \\
\hline Social background & Education & Social standing & Social mobility & \\
\hline \multirow{3}{*}{ Wisdom } & Intelligence & Capabilities & Judgment & \\
\hline & Knowledge & Language fluency & & \\
\hline & Activeness & Agility & Assertiveness & Passion \\
\hline \multirow[t]{2}{*}{ Character traits } & Extroversion & Independence & Creativity & \\
\hline & Confidence & Integration of personality & & \\
\hline \multirow{2}{*}{ Work-related traits } & Achievements & Responsibility & Creativity & Persistence \\
\hline & Entrepreneurialism & Work-orientation & & \\
\hline \multirow{3}{*}{ Social traits } & Administrative skills & Attractiveness & Cooperation & Popularity \\
\hline & Reputation & Social skills & Interpersonal skills & Resourcefulness \\
\hline & Diplomacy & & & \\
\hline
\end{tabular}

\subsection{Competence}

\subsubsection{Definition of Competence}

The earliest definition of competence was provided by McClelland [25], who held that regardless of a person's race, sex, or socioeconomic status, competence is the paramount predictor of job performance. He discovered that behavioral characteristics and content (e.g., attitude, cognition, and individuality) are the most effective test traits. Ulrich et al. [26] defined competence as knowledge and skills that an individual possesses or outwardly displays. After Spencer and Spencer [27] proposed the iceberg model of competence, definitions of competence became more concrete, and many scholars and companies have attained more solid understandings of what competence means and developed more diversified forms of managing and fostering employees' professional competence. Derouen and Kleiner [28] distinguished competence by type into technical competence, people competence, and conceptual competence, and on this basis, subsequent scholars have developed more specific competencies applicable to all company hierarchies. Companies also outsource the development of training frameworks; for example, Taiwan's Talent Quality-Management System (TTQS) features classes on professional competence in its corporate consultation courses [29]. Müller-Frommeyer [30] also constructed a competence framework based on learning environments, which is summarized in Table 4:

Table 4. Overview of competencies.

\begin{tabular}{cc}
\hline & Knowledge of science and mechanics \\
\cline { 2 - 3 } Professional and methodological competencies & Presentation skills \\
Technical knowledge \\
Social competencies & Application of knowledge \\
& Analytical thinking \\
& Measuring energy \\
\hline Personal competencies & Capacity for teamwork \\
& Communication skills \\
\hline & Motivation \\
& Affinity for technology \\
& Personal responsibility \\
\end{tabular}

\subsubsection{Senior Executive Competencies}

On the basis of the ranks and competencies of division managers, scholars worldwide have proposed the competencies of senior executives and the necessary core abilities and management skills; the established framework is presented in Table 5, and the references included the competencies of top management teams too, based on Brinckmann [31]. 
Table 5. Senior executive competencies.

\begin{tabular}{|c|c|}
\hline Senior Executive Competencies & References \\
\hline \multicolumn{2}{|l|}{ 1. Communication skills } \\
\hline \multicolumn{2}{|l|}{ 2. Customer-oriented abilities } \\
\hline 3. Proactiveness & Chang and Huang [32] \\
\hline \multicolumn{2}{|l|}{ 4. Self-management skills } \\
\hline \multicolumn{2}{|l|}{ 5. Problem-solving skills } \\
\hline \multicolumn{2}{|l|}{ 1. Analytical skills } \\
\hline \multicolumn{2}{|l|}{ 2. Governance skills } \\
\hline \multicolumn{2}{|l|}{ 3. Communication and coordination } \\
\hline \multicolumn{2}{|l|}{ 4. Problem-solving } \\
\hline 5. Administrative management capabilities & Newland [33] \\
\hline \multicolumn{2}{|l|}{ 6. Organizational and business capabilities } \\
\hline \multicolumn{2}{|l|}{ 7. Integration, financial, and information capabilities } \\
\hline \multicolumn{2}{|l|}{ 8. Leadership charisma and leadership abilities } \\
\hline \multicolumn{2}{|l|}{ 9. Self-understanding } \\
\hline \multicolumn{2}{|l|}{ 1. Interpersonal relationships, information capabilities, decision-making abilities } \\
\hline \multirow{2}{*}{\multicolumn{2}{|c|}{ 2. Crisis management resource integration, and business negotiations }} \\
\hline & \\
\hline \multicolumn{2}{|l|}{ 4. Innovative capabilities } \\
\hline \multicolumn{2}{|l|}{ 1. High-order heterogeneity } \\
\hline 2. Exemplary competitiveness & Hambrick et al. [35] \\
\hline 3. Adaptability & Garg and Zhao [36] \\
\hline \multicolumn{2}{|l|}{ 4. Resulting in interfirm differences } \\
\hline \multicolumn{2}{|l|}{ 1. Entrepreneurial: conceptual, creative, and executive abilities } \\
\hline 2. Functional: technical, business, and financial management abilities & Brinckmann [31] \\
\hline \multicolumn{2}{|l|}{ 3. Social: teamwork, leadership, and networking abilities } \\
\hline \multicolumn{2}{|l|}{ 1. Open-mindedness, agile thinking strategies } \\
\hline \multicolumn{2}{|l|}{ 2. Cultural interest and sensitivity } \\
\hline \multicolumn{2}{|l|}{ 3. Complex processing ability } \\
\hline 4. Flexibility, resourcefulness, optimism, and vigor & McCall and Hollenbeck [37] \\
\hline \multicolumn{2}{|l|}{ 5. Honesty and integrity } \\
\hline \multicolumn{2}{|l|}{ 6. Stability in their personal life } \\
\hline \multicolumn{2}{|l|}{ 7. Added-value technologies or business skills } \\
\hline \multicolumn{2}{|l|}{ 1. Organizational skills } \\
\hline 2. Security and crisis management skills & \\
\hline 3. Professional knowledge & \\
\hline 4. Vision planning & \\
\hline 5. Risk prediction and conflict resolution skills & \\
\hline 6. Approachability & Wang and We1 [38] \\
\hline 7. Independent learning skills & \\
\hline 8. Leadership skills & \\
\hline 9. Comprehension skills & \\
\hline 10. Leadership charisma & \\
\hline
\end{tabular}

\section{Research Method}

This study is an exploration of the key factors and order of succession in the appointment of division managers in manufacturing businesses in an attempt to construct the key competence factors for a division manager, with emphases on traits, managerial competence, core competence, and adaptability. Tsai et al. [39] argued a technique for the order preference by similarity to the ideal solution to assist evaluating candidates, and a prototype of the research framework was based on the literature on competence, both in Taiwan and internationally. This preliminary framework was also the basis of an expert questionnaire survey administered to senior executives and top-level business operators who have over 10 years of experience in manufacturing businesses that are publicly listed in Taiwan. These businesses are $\mathrm{M}$-form companies. The respondents were surveyed on the following: when suggesting or appointing a division manager in the event of establishing a division or filling a vacancy, what key factors and criteria do they consider to 
determine the prime candidate for division manager? The surveys were anonymous: the experts did not discuss the survey among themselves, nor did lateral communications occur. After explaining the research method and topics, the care taken to avoid ethics violations, the rights to privacy of the respondents, and their consent was obtained before they provided responses.

Figure 2 depicts the research process flowchart.

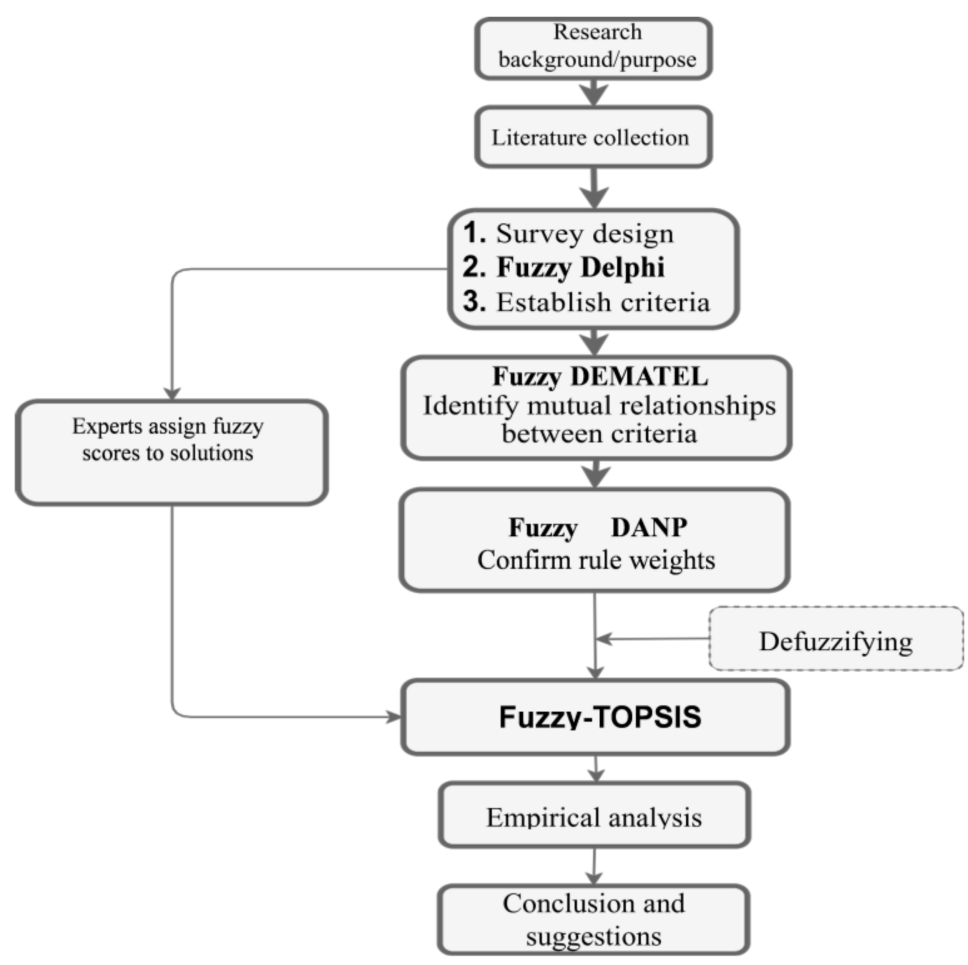

Figure 2. Research process flowchart.

\subsection{Research Framework}

The division manager dimensions and criteria were constructed on the basis of the literature review. The prototype comprises four dimensions and 22 criteria (Figure 3), alternative 1 to alternative 4 represent the four managers ranked; the definitions and source references are listed in Table 6.

Table 6. Prototype dimensions and criteria.

\begin{tabular}{|c|c|c|c|c|}
\hline Dimensions & Criteria & & Definitions & Citations \\
\hline \multirow{10}{*}{$\begin{array}{l}\text { Senior } \\
\text { executive } \\
\text { traits } \\
(1 \text { to T6) }\end{array}$} & 1 & Engagement & $\begin{array}{l}\text { Is dedicated to the profession and gets along } \\
\text { with colleagues }\end{array}$ & \multirow{10}{*}{$\begin{array}{l}\text { Boyatzis [40]; Tu [17]; } \\
\text { Hsiao [20]; Newland [33] } \\
\text { Ivancevich et al. [19] } \\
\text { Wang and Wei [38]. } \\
\text { Hambrick et al. [35] }\end{array}$} \\
\hline & 2 & Open honesty & Handles matters with integrity & \\
\hline & 3 & $\begin{array}{l}\text { Level of } \\
\text { education }\end{array}$ & $\begin{array}{l}\text { The highest level of education received or } \\
\text { research field }\end{array}$ & \\
\hline & \multirow{3}{*}{4} & \multirow{3}{*}{$\begin{array}{l}\text { Team } \\
\text { heterogeneity }\end{array}$} & Has a different length of experience in the company, & \\
\hline & & & different professional background, and different & \\
\hline & & & educational background from most team members & \\
\hline & & Emotional & Is proficient in self-control, coordination, and & \\
\hline & 5 & management & $\begin{array}{l}\text { emotional regulation and is able to resolve conflicts in } \\
\text { the organization and respond appropriately to events }\end{array}$ & \\
\hline & & & Is charismatic with lower-ranked employees, resulting & \\
\hline & 6 & $\begin{array}{l}\text { Leadership } \\
\text { charisma }\end{array}$ & $\begin{array}{l}\text { in their willingness to be led; exhibits outstanding } \\
\text { leadership abilities in the company or the ability to }\end{array}$ & \\
\hline
\end{tabular}


Table 6. Cont.

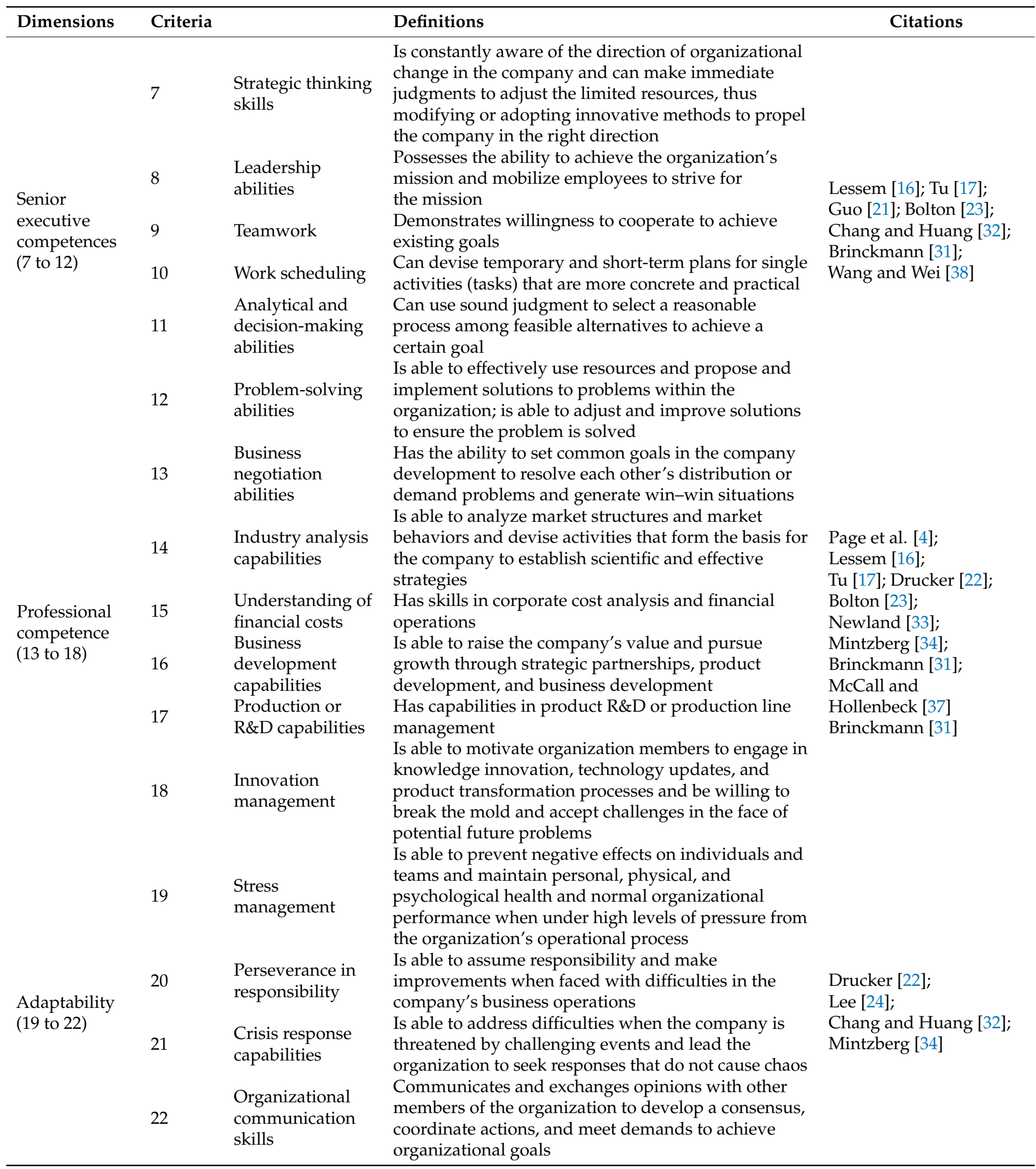




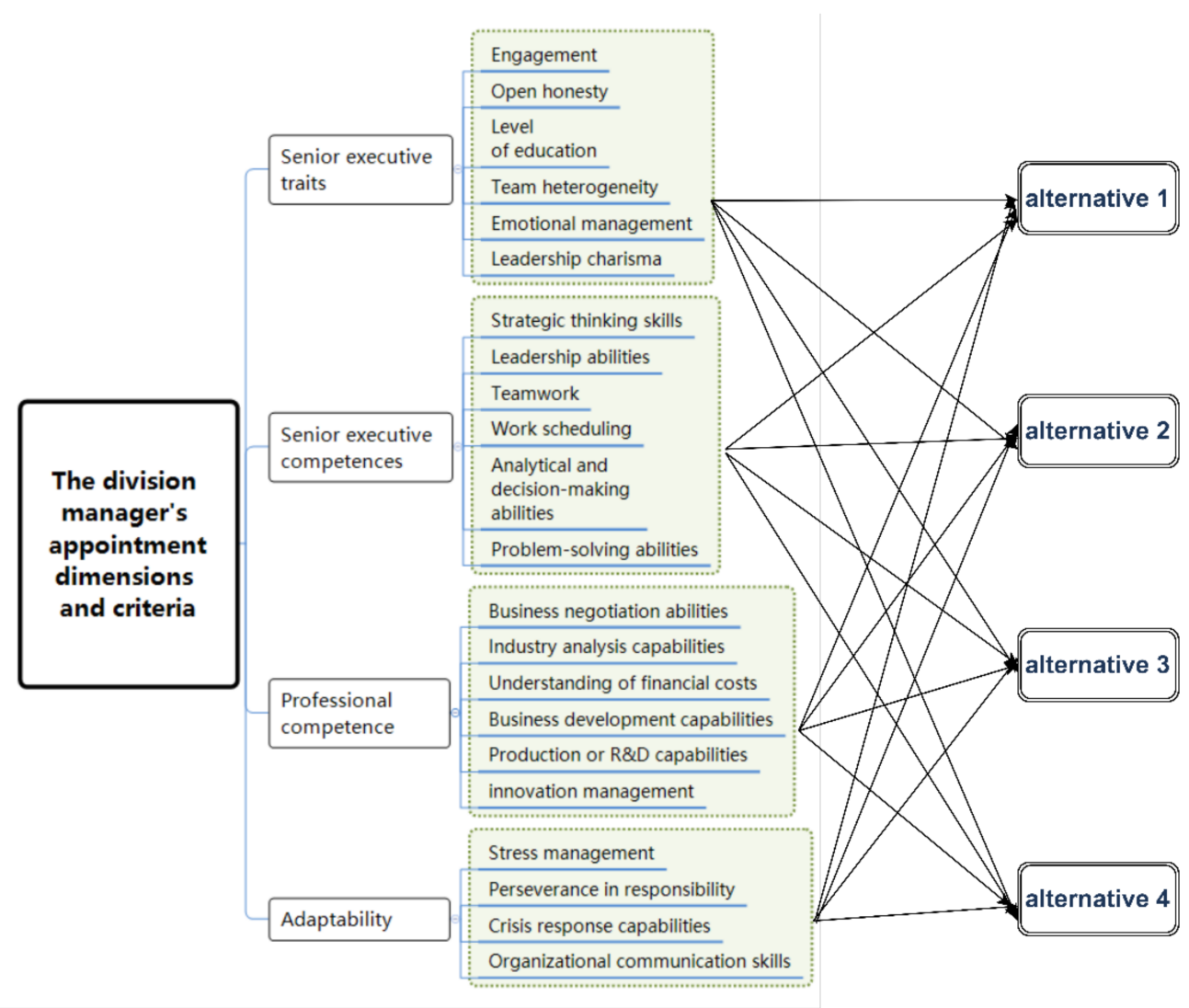

Figure 3. Research framework.

\subsection{Fuzzy Set Theory}

Bellman and Zadeh [41] argued that in every environment, an overwhelming majority of decision processes are filled with uncertain circumstances and limitations. Chen and Hwang [42] also explained that the decisions we make in fuzzy environments are typically subjective and uncertain, and the main reasons include "the information is unquantifiable", "the information is incomplete", and "the information cannot be disclosed". To address these types of problems, University of California, Berkeley Professor Zadeh [43] proposed using mathematical models for fuzzy decision-making in an attempt to represent fuzzy phenomena in the real world quantitatively. This theory changed the traditionally two-dimensional crisp sets with membership values ranging from 0 to 1 . Al-Najjar and Alsyouf [44] indicated that fuzzy logic can be used to represent and process problems that are fuzzy, unclear, or lack sufficient information to improve the accuracy of decision-making evaluations.

This study involves simplified fuzzy calculations, the selection of triangular fuzzy numbers, and the integration of expert opinions to represent fuzzy semantics [45].

\subsubsection{Triangular Fuzzy Numbers}

Triangular fuzzy numbers are expressed as $\mathrm{M}(l, m, u)$, in which $l \leq m \leq u$. When 0 is greater than $l, \mathrm{M}$ is considered a positive triangular fuzzy number, and the membership function of the positive triangular fuzzy number $\mathrm{T}$ is $\mu \mathrm{a}(x)$. The membership function is defined as follows [46] and depicted in Figure 4:

$$
U_{A}\left(x_{0}\right)=\left\{\begin{array}{l}
(x-l) /(m-l), l \leq x \leq m \\
(x-u) /(m-u), m \leq x \leq u \\
0, \text { other }
\end{array}\right.
$$




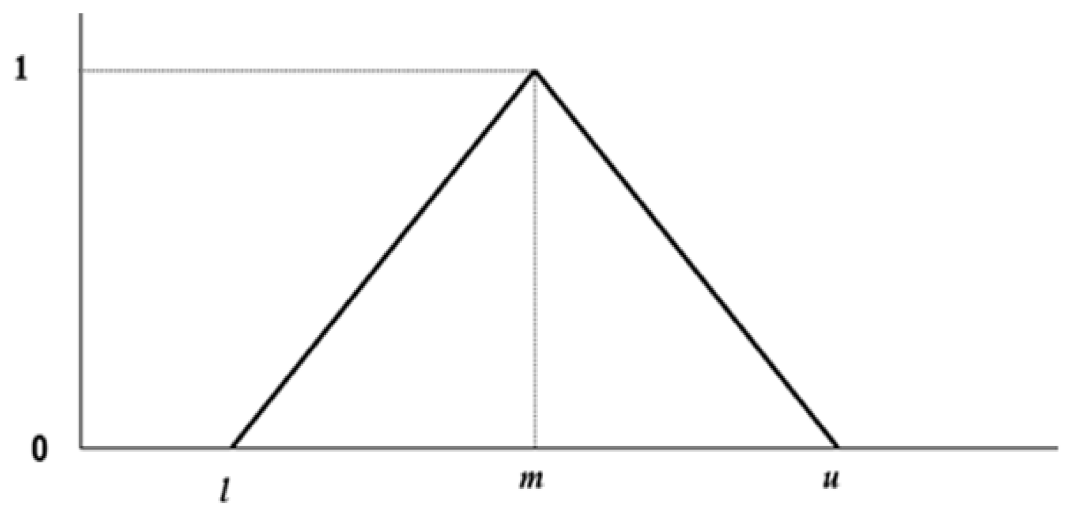

Figure 4. Triangular fuzzy number.

In this equation, $l, m$, and $u$ represent the smallest, mean, and greatest possible values in the fuzzy event. Figure 4 indicates how triangular fuzzy numbers are expressed.

\subsubsection{Fuzzy Number Calculations}

Zimmerman [47] proposed that the nature and expansion principles of a fuzzy number, assuming two triangular fuzzy numbers, are expressed as $M_{1}=\left(l_{1}, m_{1}, u_{1}\right)$ and $M_{2}=\left(l_{2}\right.$, $\left.m_{2}, u_{2}\right)$; therefore, the fuzzy calculations are as follows:

Addition: $M 1 \oplus M 2=\left(l_{1}+l_{2}, m_{1+} m_{2}, u_{1}+u_{2}\right)$

Subtraction: $M 1 \Theta M 2=\left(l_{1}-l_{2}, m_{1}-m_{2}, u_{1}-u_{2}\right)$

Multiplication: $M 1 \otimes M 2=\left(l_{1} \times l_{2}, m_{1} \times m_{2}, u_{1} \times u_{2}\right)$

Division: $M_{1} / M_{2}=\left(l_{1} / l_{2}, m_{1} / m_{2}, u_{1} / u_{2}\right)$

\subsubsection{Semantic Variables}

Chang [48] argued that semantic variables are fuzzy sets that are used in designated fields to describe natural language. In this manner, narratives in natural languages can be classified into logical narratives through logical reasoning. Semantic variables use words or sentences as values, rather than numerical values. Semantic variables can appropriately express an assessor's subjective judgments and are used to process ambiguous messages. These semantic variables are used to express an assessor's perception of certain matters. Figure 5 displays the semantic variables scale, with converted semantic words into fuzzy semantic variables, which are indicated by fuzzy numbers with interval values; Table 7 presents the fuzzy semantics scale comparing relative importance. However, respondents have disparate views on importance, and the semantic values should be determined by the respondents according to their preferences. Figure 6 displays the respondents' subjective perceptions of the semantic values which can be confirmed beforehand with a questionnaire, and then a triangular fuzzy number can be built according to the respondents' perceived values [49].

Table 7. Fuzzy semantics scale comparing relative importance.

\begin{tabular}{ccc}
\hline Scale & Semantic Value & Triangular Fuzzy Number \\
\hline 1 & Disagree strongly & $(0.1,0.1,0.3)$ \\
2 & Disagree & $(0.1,0.3,0.5)$ \\
3 & Neutral & $(0.3,0.5,0.7)$ \\
4 & Agree & $(0.5,0.7,0.9)$ \\
5 & Strongly agree & $(0.7,0.9,0.9)$ \\
\hline
\end{tabular}




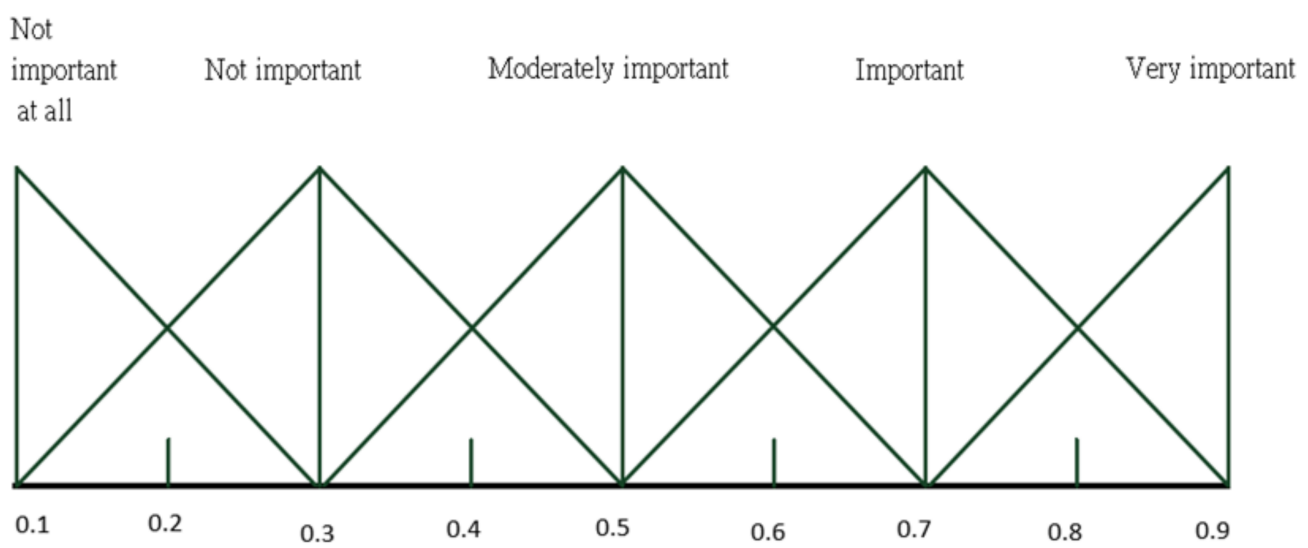

Figure 5. Semantic variables scale.

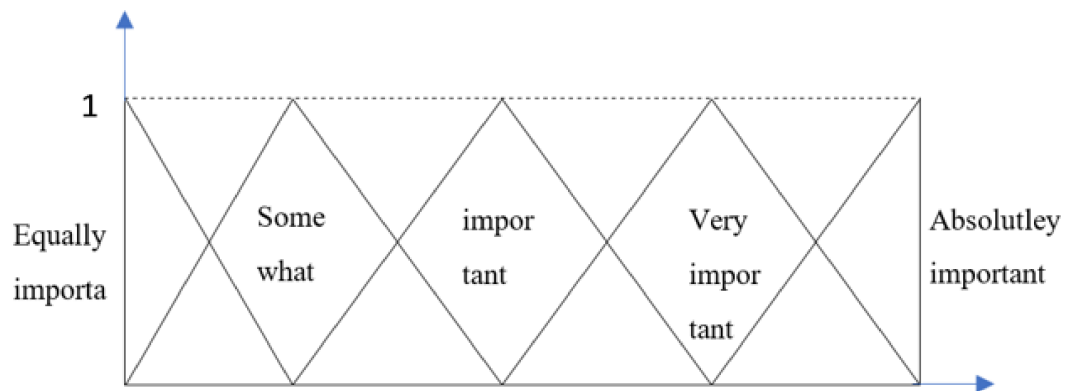

1
A
B
C

9

\begin{tabular}{|c|c|}
\hline Scale & Fuzzy number \\
\hline Equally important & $(1,1,1)$ \\
\hline Somewhat important & $(1, \mathrm{~A}, \mathrm{~B})$ \\
\hline Important & $(\mathrm{A}, \mathrm{B}, \mathrm{C})$ \\
\hline Very important & $(\mathrm{B}, \mathrm{C}, 9)$ \\
\hline Absolutely important & $(\mathrm{C}, 9,9)$ \\
\hline
\end{tabular}

Figure 6. Converting the respondents' semantic values into fuzzy numbers.

\subsection{Fuzzy Delphi}

Fuzzy Delphi is a method of using questionnaires to survey expert predictions and was first proposed by Murray et al. [50] to address problems with ambiguity in the conventional Delphi method by incorporating fuzzy theories. Klir and Folger [51] incorporated generalized means into the Delphi method, and they then used expert surveys to construct triangular fuzzy functions, using geometric functions to represent the expert panel values. The study results indicated that the researchers reached a consensus on the threshold values for selecting appropriate evaluation factors.

Ishikawa et al. [52] further used the distribution of cumulative frequencies and concepts of fuzzy integrals to integrate expert opinions into fuzzy numbers. This process is known as fuzzy Delphi.

\subsubsection{Constructing Triangular Fuzzy Numbers}

With reference to the use of triangular fuzzy functions by Hsu [53] to integrate the opinions of experts, a fuzzy Delphi computing architecture was constructed using the greatest and smallest values in the expert opinions as the two ends of the triangular fuzzy number. The geometric mean value represented the consensus among the majority of experts in the decision-making process. Huang et al. [54] proposed that triangular fuzzy numbers can effectively reflect the fuzzy values of quantitative data and language approximation concepts, with higher stability and representativeness in small samples.

Using Equations (1)-(4), triangular fuzzy numbers (Figure 7) were built for each influencing factor from the assessed values of each criterion in the expert survey.

$$
\tilde{\mathrm{A}}=\left(\mathrm{L}_{\mathrm{A}}, \mathrm{M}_{\mathrm{A}}, \mathrm{U}_{\mathrm{A}}\right)
$$




$$
\begin{aligned}
\mathrm{L}_{\mathrm{A}} & =\min \left(\mathrm{X}_{\mathrm{Ai}}\right), \mathrm{i}=1,2,3 \ldots, \mathrm{n} \\
\mathrm{M}_{\mathrm{A}} & =\sqrt[\mathfrak{n}]{\mathrm{X}_{\mathrm{A} 1} \times \mathrm{X}_{\mathrm{A} 2} \times \ldots \times \mathrm{X}_{\mathrm{An}}} \\
\mathrm{U}_{\mathrm{A}} & =\max \left(\mathrm{X}_{\mathrm{Ai}}\right), \mathrm{i}=1,2,3 \ldots, \mathrm{n}
\end{aligned}
$$

$\mathrm{X}_{\mathrm{Ai}}$ : The value of factor $\mathrm{A}$ as assessed by decision maker

$\mathrm{L}_{\mathrm{A}}$ : The minimum assessed value of factor $\mathrm{A}$ by the decision group (lower bound)

$\mathrm{M}_{\mathrm{A}}$ : The geometric mean of the assessed value of factor $\mathrm{A}$ by the decision group

$\mathrm{U}_{\mathrm{A}}$ : The maximum assessed value of factor $\mathrm{A}$ by the decision group (upper bound)

A: Influencing factor

i: Decision maker

Ã: Fuzzy number of the importance of influencing factor A

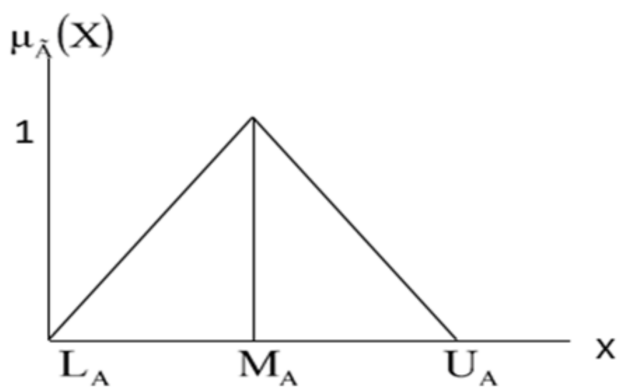

Figure 7. Diagram of a triangular fuzzy number (decision group consensus).

\subsubsection{Defuzzified Numbers}

The method proposed by Teng and Tzeng [55] that is based on the center of the triangle, also known as the center of gravity (COG) method, was used to determine the defuzzified values of the triangular fuzzy numbers calculated in the prior step. If the defuzzified value is $S_{A}$, it is calculated with the following equation:

$$
\mathrm{S}_{\mathrm{A}}=\frac{\left(\mathrm{M}_{\mathrm{A}}-\mathrm{L}_{\mathrm{A}}\right)+\left(\mathrm{U}_{\mathrm{A}}-\mathrm{L}_{\mathrm{A}}\right)}{3}+\mathrm{L}_{\mathrm{A}}
$$

\subsubsection{Selecting Indices}

Finally, fuzzy Delphi uses the defuzzified values from the previous step to filter and select indices. According to the threshold value $T$ set by the researchers, more favorable evaluation criteria can be selected out of all the factors. In this study, the arithmetic mean of every expert was used as the threshold value; the calculations were as follows:

1. If $S_{A} \geq T$, then factor $\mathrm{A}$ is accepted as an evaluation index

2. If $S_{A}<T$, then factor $A$ is eliminated

\subsection{Fuzzy DEMATEL}

First developed by the Geneva Research Centre of the Battelle Memorial Institute in 1973, the decision-making trial and evaluation laboratory (DEMATEL) can be used to effectively analyze complicated causal relationships. In addition, by testing the degrees of influence between factors, DEMATEL can determine the causal relationships and strengths of influence among factors using matrices. Because of environmental uncertainties and semantic ambiguity, Lin and $\mathrm{Wu}$ [56] introduced fuzzy theories into DEMATEL to create fuzzy DEMATEL, which involves steps requiring the experts to first set the fuzzy semantic values (0-9), followed by the analysis of the defuzzified and normalized results.

When mutual factors are involved, five degrees of mutual influence are observed among the respondents' subjective values in terms of the semantics: no influence, low influence, medium influence, high influence, and very high influence [57]. The triangular fuzzy numbers are demonstrated in Figure 8. 


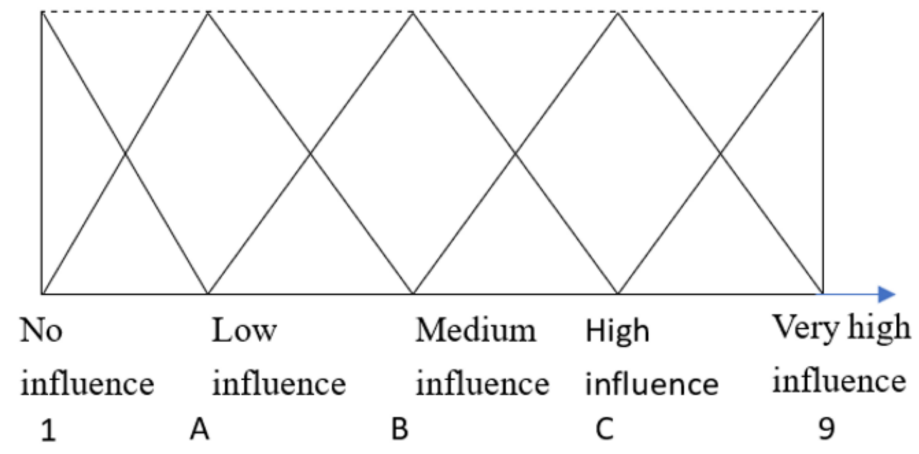

\begin{tabular}{|c|c|c|}
\hline & Scale & Fuzzy number \\
\hline 0 & No influence & $(1,1,1)$ \\
\hline 1 & Low influence & $(1, \mathrm{~A}, \mathrm{~B})$ \\
\hline 2 & Medium influence & $(\mathrm{A}, \mathrm{B}, \mathrm{C})$ \\
\hline 3 & High influence & $(\mathrm{B}, \mathrm{C}, 9)$ \\
\hline 4 & Very high influence & $(\mathrm{C}, 9,9)$ \\
\hline
\end{tabular}

Figure 8. Fuzzy DEMATEL triangular fuzzy numbers.

\subsubsection{Establishing the Direct-Correlation Matrix}

After paired tests of the criteria are performed, the initial fuzzy direct-correlation matrix can be obtained.

$$
\widetilde{\mathrm{Z}}=\begin{gathered}
C_{1} \\
C_{2} \\
\vdots \\
C_{n}
\end{gathered}\left[\begin{array}{cccc}
\widetilde{0} & \widetilde{z}_{12} & \cdots & \widetilde{z}_{1 n} \\
\widetilde{z}_{21} & \widetilde{0} & \cdots & \widetilde{z}_{2 n} \\
\vdots & \vdots & \ddots & \vdots \\
\widetilde{z}_{n 1} & \widetilde{z}_{n 2} & \cdots & 0
\end{array}\right]
$$

\subsubsection{Establishing and Analyzing the Structural Model}

The linear scale was converted into a normalized equation, which was used to convert the criteria scale into a comparable scale, as follows:

$$
\widetilde{a}_{i j}=\sum_{j=1}^{n} \widetilde{z}_{i j}=\left(\sum_{j=1}^{n} l_{i j}, \sum_{j=1}^{n} m_{i j}, \sum_{j=1}^{n} r_{i j}\right)
$$

In this, $r=\max \left(\max _{1 \leq i \leq n}\left(\sum_{j=1}^{n} r_{i j}\right), \max _{1 \leq j \leq n}\left(\sum_{i=1}^{n} r_{i j}\right)\right)$

\subsubsection{Normalizing the Fuzzy Direct-Correlation Matrix}

By using $\widetilde{X}$, the normalized fuzzy direct-correlation matrix can be obtained:

$\widetilde{X}=r^{-1} \otimes \widetilde{z}$, therefore

$$
\widetilde{X}=\left[\begin{array}{cccc}
\widetilde{x}_{11} & \widetilde{x}_{12} & \cdots & \widetilde{x}_{1 n} \\
\widetilde{x}_{21} & \widetilde{x}_{22} & \cdots & \widetilde{x}_{2 n} \\
\vdots & \vdots & \ddots & \vdots \\
\widetilde{x}_{m 1} & \widetilde{x}_{m 2} & \cdots & \widetilde{x}_{m n}
\end{array}\right] \text { and } \widetilde{x}_{i j}=\frac{\widetilde{z}_{i j}}{r}=\left(\frac{l_{i j}}{r}, \frac{m_{i j}}{r}, \frac{r_{i j}}{r}\right)
$$

\subsubsection{Fuzzy Total-Influence Matrix}

After the normalized direct-correlation matrix is obtained, the total-influence matrix can be determined using the following equation: 


$$
\begin{gathered}
\widetilde{T}=\widetilde{X}+\widetilde{X}^{2}+\ldots+\widetilde{X}^{k} \\
=\widetilde{X}\left(I+\widetilde{X}+\widetilde{X}^{2}+\ldots+\widetilde{X}^{k-1}\right) \\
=\widetilde{X}\left(I+\widetilde{X}+\widetilde{X}^{2}+\ldots+\widetilde{X}^{k-1}\right)(I-\widetilde{X})(I-\widetilde{X})^{-1} \\
=\widetilde{X}(I-\widetilde{X})^{-1}, \text { when } \lim _{k \rightarrow \infty} \widetilde{X}^{k}=[0]_{n x n} \widetilde{T} \\
=\left[\begin{array}{cccc}
\widetilde{t}_{11} & \widetilde{t}_{12} & \cdots & \widetilde{t}_{1 n} \\
\widetilde{t}_{21} & \widetilde{t}_{22} & \cdots & \widetilde{t}_{2 n} \\
\vdots & \vdots & \ddots & \vdots \\
\widetilde{t}_{m 1} & \widetilde{t}_{m 2} & \cdots & \widetilde{t}_{m n}
\end{array}\right] \text { and } \widetilde{t}_{i j}=\left(l_{i j}^{\prime \prime}, m_{i j}^{\prime \prime}, r_{i j}^{\prime \prime}\right) \\
{\left[l_{i j}^{\prime \prime}\right]=\widetilde{X}_{I}\left(I-\widetilde{X}_{I}\right)^{-1}} \\
{\left[M_{i j}^{\prime \prime}\right]=\widetilde{X}_{m}\left(I-\widetilde{X}_{m}\right)^{-1}} \\
{\left[r_{i j}^{\prime \prime}\right]=\widetilde{X}_{r}\left(I-\widetilde{X}_{r}\right)^{-1}}
\end{gathered}
$$

3.4.5. After the Row and Column Sums Were Defuzzified to Determine the Row and Column Values, They Were Defined As $d$ and $r$

$$
T=\left[t_{i j}\right], i, j \in\{1,2, \ldots, \mathrm{n}\} d=\left(d_{i}\right)_{n \times 1}=\left[\sum_{j=1}^{n} t_{i j}\right]_{n \times 1} ; r=\left(r_{j}\right)_{1 \times \mathrm{n}}^{\prime}=\left[\sum_{i=1}^{n} t_{i j}\right]_{1 \times \mathrm{n}}^{\prime}
$$

A diagram of the causal relationships among the criteria can be drawn by calculating $d+r$ and $d-r$. The strength of the influence between $d+r$ criteria is also known as the centrality, with a greater value indicating a stronger influence; by contrast, $d-r$ represents the influence relationship between criteria and is also known as the causality. This is used to represent the different degrees to which criteria influence and are influenced. When $d-r$ is a negative value and when the value is lower, this indicates that the criterion is an effect that is influenced by other criteria [58].

\subsection{Fuzzy DEMATEL-Based Analytic Network Process}

The DEMATEL-based analytic network process (DANP) uses DEMATEL to confirm the different degrees of influence among the criteria. Using the "dynamic influence relationship and importance" implied in the DEMATEL total-influence matrix and continuously multiplying the matrix, the stable results of the convergence among the assessment attributes were determined. This approach is the same as the concept of using a questionnaire to confirm criteria impact and importance in an analytic network process.

With reference to the DANP framework proposed by Hu et al. [59], the fuzzy DEMATEL total-influence matrix was transformed into a fuzzy DANP (F-DANP) group priority matrix, which was then normalized and self-multiplied until convergent. The results were then defuzzified using COG to determine the criteria weights.

\subsection{Fuzzy Technique for Order of Preference by Similarity to Ideal Solution}

Technique for order of preference by similarity to ideal solution (TOPSIS) is a multiple criteria decision-making method developed by Hwang and Yoon [60]. It is applied in scenarios with a high degree of certainty by simultaneously comparing the relative distances of the decision plan with the optimal plan and the poorest plan to rank the decision plans from best to worst. In this study, fuzzy theories were integrated with TOPSIS to rank the criteria for appointing division managers. The criterion weights used in the calculations were derived from the F-DANP results, which were the basis for correcting shortcomings in the subjective determination of weights in TOPSIS.

The process is as follows. 
1. Convert the decision-making problem into a fuzzy rating matrix

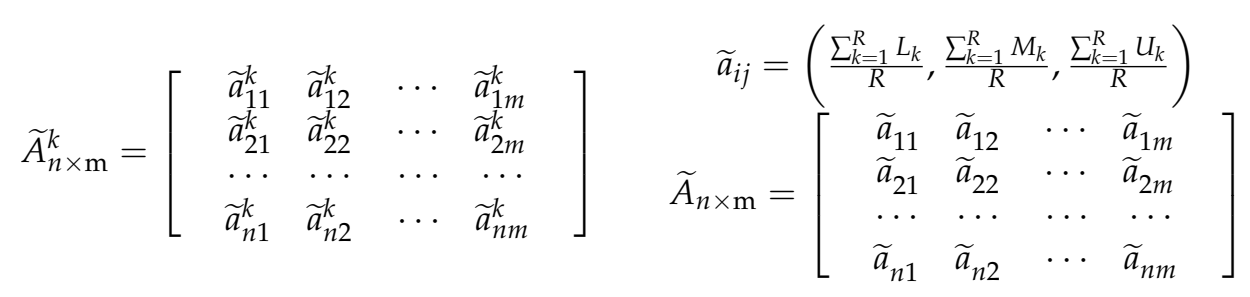

Here, the performance of plan $i$ under criterion $j$ is aij. If the decision-making problem has $n$ number of candidate plans $(i=1,2, \ldots, n)$ and $m$ number of assessment criteria $(j=1,2, \ldots, m)$, then the semantic variable is the score of the plan under the criterion performance to obtain the fuzzy rating matrix of the $k$ th expert $\left(\tilde{\mathrm{A}}^{\mathrm{K}}\right)$. The semantic variables and scales were based on the method proposed by Buckley [61] for calculating the fuzzy ratings of the expert decisions (Figure 9).

2. Set the fuzzy weights of each assessment criteria to determine the fuzzy weight decision matrix

$$
\widetilde{V}_{i j}=W_{j} \widetilde{A}=\left[\begin{array}{cccc}
\widetilde{v}_{11} & \widetilde{v}_{12} & \cdots & \widetilde{v}_{1 m} \\
\widetilde{v}_{21} & \widetilde{v}_{22} & \cdots & \widetilde{v}_{2 m} \\
\cdots & \cdots & \cdots & \cdots \\
\widetilde{v}_{n 1} & \widetilde{v}_{n 2} & \cdots & \widetilde{v}_{n m}
\end{array}\right]
$$

The clear criterion weights determined using F-DANP are used to calculate the TOPSIS weights. $\mathrm{W}_{\mathrm{J}}=[\mathrm{W} 1, \mathrm{~W} 2, \ldots, \mathrm{Wm}]$

3. Set the fuzzy positive ideal value and negative ideal value of each criterion

$$
\begin{aligned}
& \widetilde{A}^{+}=\left\{\widetilde{v}_{1}^{+}, \widetilde{v}_{2}^{+}, \ldots, \widetilde{v}_{m}^{+}\right\}, \text {where } j=1,2, \ldots, m \\
& \widetilde{A}^{-}=\left\{\widetilde{v}_{1}^{-}, \widetilde{v}_{2}^{-}, \ldots, \widetilde{v}_{m}^{-}\right\}, \text {where } j=1,2, \ldots, m
\end{aligned}
$$

4. Calculate the distances between each plan and the positive ideal value and negative ideal value Using fuzzy TOPSIS (F-TOPSIS), when choosing any two fuzzy numbers$\left(L_{1}, M_{1}, U_{1}\right)$ and $\left(L_{2}, M_{2}, U_{2}\right)$ in this case-with $D$ as the distance, the equation is as follows:

$$
D=\sqrt{\frac{\left(L_{1}-L_{2}\right)^{2}+\left(M_{1}-M_{2}\right)^{2}+\left(U_{1}-U_{2}\right)^{2}}{3}}
$$

5. The distance to the positive ideal solution and the distance to the negative ideal solution can then be determined

$$
\begin{aligned}
& D_{i}^{+}=\sum_{j=1}^{m} D\left(\widetilde{v}_{i j}, \widetilde{v}_{j}^{+}\right), i=1,2, \ldots, n \\
& D_{i}^{-}=\sum_{j=1}^{m} D\left(\widetilde{v}_{i j}, \widetilde{v}_{j}^{-}\right), i=1,2, \ldots, n
\end{aligned}
$$

6. Calculate and rank the relative closeness $(R C)$ with the ideal solutions to determine the optimal solution; the equation is as follows:

$$
R C_{j}=\frac{D_{j}^{-}}{D_{j}^{+}+D_{j}^{-}}
$$

7. The solution with the greatest distance from the negative ideal solution is the optimal solution; therefore, the greater the $\mathrm{RC}$ value is, the more favorable the solution is, and each solution is ranked by its RC value to determine the optimal solution. 


Semantic variable $\quad$ Scale $\quad$ Triangular fuzzy numbers

(TFNS)

\begin{tabular}{lll} 
& & \multicolumn{1}{c}{$\tilde{a}_{i j}=\left(l_{i j}, m_{i j}, u_{i j}\right)$} \\
\hline Poor performance (VL) & $\tilde{1}$ & $(0,0,2,0.4)$ \\
Insufficient performance (L) & $\tilde{2}$ & $(0.2,0.4,0.6)$ \\
Mediocre performance (M) & $\tilde{3}$ & $(0.4,0,6,0.8)$ \\
Favorable performance (H) & $\widetilde{4}$ & $(0.6,0.8,1)$ \\
Outstanding performance (VH) & $\widetilde{5}$ & $(0.8,1,1)$
\end{tabular}

Figure 9. Relationships between semantics and triangular fuzzy numbers.

\section{Empirical Analysis}

The purpose of this study was to construct a model for assessing division manager candidates, verified against Taiwan's manufacturing industry, and to determine successors within organizations. The previous section provides details on the research method used in this study. This section introduces actual cases and the use of F-TOPSIS to determine the priority of the solutions and candidates.

\subsection{Developing a Division Manager Competence Framework}

In this study, the criteria and key factors for assessing division manager candidates were developed on the basis of a literature review and assessments. Subsequently, using fuzzy Delphi, 12 experts assessed and confirmed the framework and criteria.

\subsubsection{Importance and Degree of Association}

In accordance with fuzzy DEMATEL calculation steps, the direct-influence matrix based on constructs and criteria was determined according to the fuzzy numbers $L, M$, and $U$. Finally, after COG defuzzification, the fuzzy total-influence matrix of the constructs and criteria was obtained (Table 8); Table 8 shows senior executive competence and a twoway relationship with senior executive traits. Subsequently, using the fuzzy DEMATEL method of Lin and Wu [55], the importance and degree of association of each criterion was determined (Table 9, Figure 10).

\subsubsection{Determining the Weights of the Division Appointment Criteria}

Through F-DANP, the fuzzy weights of each criterion and the constructs were determined (Table 10) to form the basis for calculating the F-TOPSIS weights of the Divisional Management Appointment Criteria.

Table 8. Fuzzy DEMATEL total-influence matrix of the defuzzified constructs.

\begin{tabular}{cccccc}
\hline & Constructs & C1 & C2 & C3 & C4 \\
\cline { 3 - 6 } & & $\begin{array}{c}\text { Senior Executive } \\
\text { Traits }\end{array}$ & $\begin{array}{c}\text { Senior Executive } \\
\text { Competence }\end{array}$ & $\begin{array}{c}\text { Professional } \\
\text { Competence }\end{array}$ & Adaptability \\
\hline C1 & Senior executive traits & 0.478 & 0.693 & 0.784 & 0.882 \\
C2 & Senior executive competence & 0.695 & 0.662 & 0.951 & 1.087 \\
C3 & Professional competence & 0.530 & 0.683 & 0.556 & 0.760 \\
C4 & Adaptability & 0.527 & 0.631 & 0.658 & 0.589 \\
\hline
\end{tabular}


Table 9. Importance and causality of each criterion.

\begin{tabular}{lccccc}
\hline & T & $\mathbf{D}$ & $\mathbf{R}$ & $\mathbf{D}+\mathbf{R}$ & $\mathbf{D}-\mathbf{R}$ \\
\hline A1 & Engagement & 6.31 & 5.66 & 11.98 & 0.65 \\
A2 & Team heterogeneity & 7.53 & 7.47 & 15.00 & 0.05 \\
A3 & Emotional management & 6.49 & 6.70 & 13.19 & -0.22 \\
A4 & Leadership charisma & 6.79 & 7.43 & 14.22 & -0.64 \\
A5 & Strategic thinking skills & 7.15 & 7.51 & 14.67 & -0.36 \\
A6 & Leadership abilities & 7.80 & 7.25 & 15.05 & 0.55 \\
A7 & Analytical and decision-making abilities & 7.15 & 7.26 & 14.41 & -0.11 \\
A8 & Problem-solving abilities & 7.64 & 7.41 & 15.05 & 0.22 \\
A9 & Business negotiation abilities & 7.62 & 7.38 & 15.00 & 0.24 \\
A10 & Industry analysis capabilities & 6.58 & 6.40 & 12.98 & 0.19 \\
A11 & Business development capabilities & 7.76 & 6.04 & 13.79 & 1.72 \\
A12 & Innovative management & 5.24 & 5.80 & 11.04 & -0.56 \\
A13 & Stress management & 6.84 & 7.57 & 14.40 & -0.73 \\
A14 & Perseverance in responsibility & 6.11 & 6.97 & 13.08 & -0.85 \\
A15 & Crisis response capabilities & 6.59 & 7.02 & 13.61 & -0.44 \\
A16 & Organizational communication skills & 7.39 & 7.11 & 14.50 & 0.28 \\
\hline
\end{tabular}

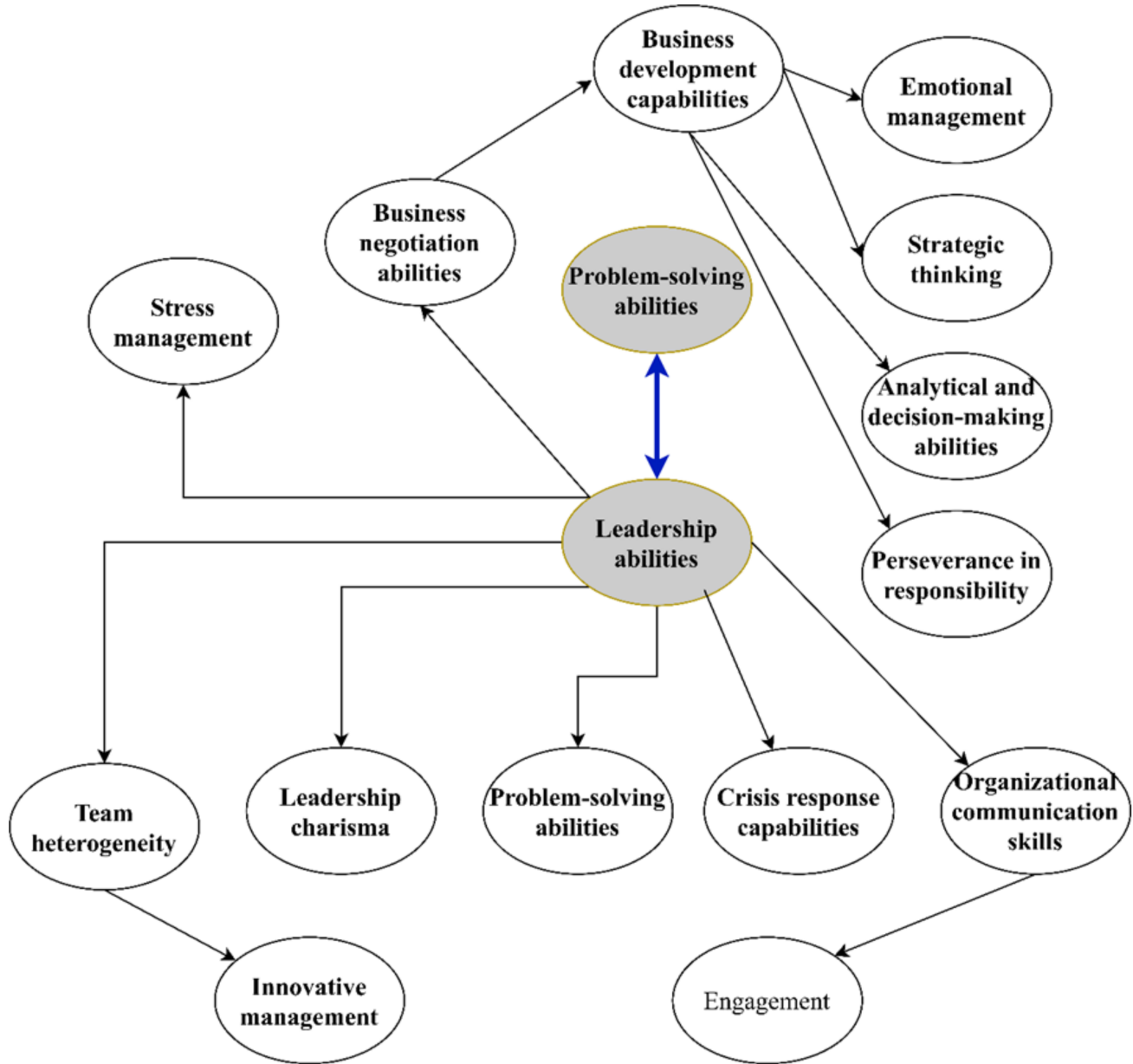

Figure 10. Network of influences. 
Table 10. F-DANP criteria weights.

\begin{tabular}{|c|c|c|c|c|c|}
\hline & Criteria & Weights & Construct & Weight & Rank \\
\hline A1 & Engagement & 0.0479 & \multirow{5}{*}{ Senior executive traits } & \multirow{5}{*}{0.2454} & \multirow{4}{*}{3} \\
\hline $\mathrm{A} 2$ & Team heterogeneity & 0.0696 & & & \\
\hline A3 & Emotional management & 0.0597 & & & \\
\hline A4 & Leadership charisma & 0.0683 & & & \\
\hline A5 & Strategic thinking skills & 0.0701 & & & \\
\hline A6 & Leadership abilities & 0.0664 & \multirow{2}{*}{ Senior executive competence } & \multirow{2}{*}{0.2725} & \multirow{3}{*}{1} \\
\hline A7 & Analytical and decision-making abilities & 0.0667 & & & \\
\hline A8 & Problem-solving abilities & 0.0693 & \multirow{5}{*}{ Professional competence } & & \\
\hline A9 & Business negotiation abilities & 0.0680 & & \multirow{4}{*}{0.2201} & \multirow{4}{*}{4} \\
\hline A10 & Industry analysis capabilities & 0.0548 & & & \\
\hline A11 & Business development capabilities & 0.0504 & & & \\
\hline A12 & Innovative management & 0.0469 & & & \\
\hline A13 & Stress management & 0.0708 & \multirow{4}{*}{ Adaptability } & \multirow{4}{*}{0.2620} & \multirow{4}{*}{2} \\
\hline A14 & Perseverance in responsibility & 0.0624 & & & \\
\hline A15 & Crisis response capabilities & 0.0638 & & & \\
\hline A16 & Organizational communication skills & 0.0650 & & & \\
\hline
\end{tabular}

\subsection{Selecting a Plan}

The division manager appointment assessments were ranked according to F-TOPSIS and manager selection plans in the literature on the division functions; the assessed managers were from the business, $R \& D$, production, and administrative divisions. On the basis of these calculations, the distances from the fuzzy positive ideal solutions and fuzzy negative ideal solutions and the solution preferences were determined (Table 11).

\subsection{Discussion}

In business management, division managers typically must be equipped with diversified competences. To oversee products from $R \& D$ to market release and ensure the products' market competitiveness, these competences further appear to be mutually supportive. As demonstrated by the constructs in the total-influence matrix in Table 8, senior executive competence has a direct influence relationship on professional competence and adaptability and a two-way relationship with senior executive traits. As such, in the development of division managers, companies can prioritize the use of senior executive competency courses in education and training to improve the division managers' abilities to promote the operations of their departments.

In criterion importance $(d+r)$, the top four rankings were leadership abilities, business negotiations, problem-solving, and team heterogeneity. This indicates that the greater the influence of the strength of the factor, the greater the degree and importance of the influence.

As such, for appointment assessments in the division, the criterion with the most importance points to "leadership abilities" as the most important factor. This indicates that a company, when selecting the manager of any department, especially a senior executive of a department in a product division, is inclined to appoint managers with leadership capabilities. If the replacement manager's abilities are insufficient, according to the iceberg model of competency proposed by Spencer and Spencer [27], the potential competencies in the bottom half of the iceberg, which include self-concept, traits, and motive, can be obtained or increased through different combinations of training and development, work conditions, and organizational environment.

The causality of correlations among criteria $(d-r)$ demonstrated the following: business development capabilities had the greatest value as an active influencer that affected others. The greater the value is, the greater the direct influence of this factor on other factors. Therefore, business development capabilities can demonstrate its influence on other related criteria in a division manager's competence, as market development is a major performance index in the growth of a division. Having business development capabilities influences communication skills, problem-solving, business negotiation, and stress management. If a 
manager's business development capabilities are improved, the performance of other related criteria can be improved simultaneously.

Table 11. Distance from positive and negative ideal solutions and solution preferences.

\begin{tabular}{|c|c|c|c|c|c|c|c|c|}
\hline & \multicolumn{2}{|c|}{ Business Manager } & \multicolumn{2}{|c|}{ R\&D Manager } & \multicolumn{2}{|c|}{$\begin{array}{c}\text { Production } \\
\text { Manager }\end{array}$} & \multicolumn{2}{|c|}{$\begin{array}{c}\text { Administrative } \\
\text { Manager }\end{array}$} \\
\hline & FPIS & FNIS & FPIS & FNIS & FPIS & FNIS & FPIS & FNIS \\
\hline A1 & 0.005 & 0.031 & 0.032 & 0.000 & 0.006 & 0.028 & 0.006 & 0.030 \\
\hline A2 & 0.022 & 0.012 & 0.000 & 0.025 & 0.019 & 0.008 & 0.023 & 0.009 \\
\hline A3 & 0.000 & 0.019 & 0.019 & 0.000 & 0.010 & 0.015 & 0.019 & 0.000 \\
\hline A4 & 0.000 & 0.043 & 0.043 & 0.000 & 0.012 & 0.008 & 0.012 & 0.008 \\
\hline A5 & 0.000 & 0.023 & 0.014 & 0.000 & 0.023 & 0.036 & 0.018 & 0.036 \\
\hline A6 & 0.000 & 0.042 & 0.042 & 0.000 & 0.000 & 0.007 & 0.042 & 0.007 \\
\hline A7 & 0.000 & 0.024 & 0.024 & 0.000 & 0.024 & 0.036 & 0.024 & 0.036 \\
\hline A8 & 0.007 & 0.029 & 0.000 & 0.000 & 0.029 & 0.038 & 0.029 & 0.038 \\
\hline A9 & 0.000 & 0.053 & 0.053 & 0.000 & 0.053 & 0.008 & 0.028 & 0.008 \\
\hline A10 & 0.000 & 0.043 & 0.023 & 0.000 & 0.043 & 0.006 & 0.023 & 0.006 \\
\hline A11 & 0.000 & 0.044 & 0.044 & 0.000 & 0.044 & 0.006 & 0.044 & 0.006 \\
\hline A12 & 0.012 & 0.033 & 0.000 & 0.000 & 0.023 & 0.005 & 0.033 & 0.005 \\
\hline A13 & 0.000 & 0.014 & 0.014 & 0.000 & 0.008 & 0.039 & 0.014 & 0.039 \\
\hline A14 & 0.000 & 0.013 & 0.013 & 0.000 & 0.013 & 0.032 & 0.011 & 0.032 \\
\hline A15 & 0.000 & 0.040 & 0.040 & 0.000 & 0.014 & 0.007 & 0.011 & 0.007 \\
\hline A16 & 0.007 & 0.022 & 0.022 & 0.000 & 0.009 & 0.029 & 0.012 & 0.029 \\
\hline $\mathrm{di}^{+}$ & \multicolumn{2}{|c|}{0.053} & \multicolumn{2}{|c|}{0.384} & \multicolumn{2}{|c|}{0.329} & \multicolumn{2}{|c|}{0.347} \\
\hline $\mathrm{di}^{-}$ & \multicolumn{2}{|c|}{0.486} & \multicolumn{2}{|c|}{0.025} & \multicolumn{2}{|c|}{0.307} & \multicolumn{2}{|c|}{0.296} \\
\hline $\mathrm{RC}$ & \multicolumn{2}{|c|}{0.901} & \multicolumn{2}{|c|}{0.062} & \multicolumn{2}{|c|}{0.483} & \multicolumn{2}{|c|}{0.460} \\
\hline RANK & \multicolumn{2}{|c|}{1} & \multicolumn{2}{|c|}{4} & \multicolumn{2}{|c|}{2} & \multicolumn{2}{|c|}{3} \\
\hline
\end{tabular}

When the causality $(d-r)$ is negative, greater negative values indicate greater degrees of influence. In this study, perseverance in responsibility and stress management were demonstrated to be the two items with the greatest negative values and were clearly found to be easily affected by other criteria. This indicates that the increase or decrease in manager competence has a relative influence on the stress and responsibility that the manager bears. The criteria network diagram can be analyzed as follows:

1. Leadership abilities: we found that in relationship networks that tended to be centered around leadership abilities, the relative influence of the division manager's leadership abilities on other criteria is high. This indicates that companies prioritize leadership abilities as a standard for assessing division manager candidates.

2. Problem-solving abilities: problem-solving abilities and leadership abilities have a relationship of mutual influence. When a manager has strong problem-solving abilities, their organizational leadership abilities would also benefit. Conversely, when a manager has strong leadership abilities, they tend to be adept at addressing problems encountered in the company operations.

3. Organizational communication skills: organizational communication skills were found to have a relative influence on business development capabilities and engagement. Managers who have communication skills and use those skills to increase customer relationships in business, can exceed expectations by cooperating with staff of all levels in the organization and gaining their recognition. 
4. Team heterogeneity: a higher heterogeneity in the division manager suggests a certain influence on product innovation abilities. These managers may even develop new products with market differences.

Construct and criterion weights: the key considerations in division manager appointments can be observed in the known importance among the weights in Figure 10. Among the constructs, senior executive conceptual competency and adaptability have greater weights, with senior executive competence having the highest value (0.2725). However, senior executive competence cannot be improved immediately; the knowledge, perception, and thinking domains require the comprehensive integration of experience and management concepts. As such, learning management concepts and knowledge through on-the-job business administration courses or outsourced training can reinforce managers' management competence and improve their leadership and organizational capabilities. The training is typically focused on criteria relating to heterogeneity, strategic thinking, business negotiations, and problem-solving abilities. This demonstrates that a division manager's uniqueness in thinking is critical, and the behavioral patterns exhibited through their thinking allow them to lead the organization and create profits for the company.

From the 24 prototype criteria, threshold values for key factors were established after the experts' review of questionnaires, and then 16 criteria with higher values were selected for discussion. During this process, it was found that the four criteria that are highlighted in the original construction, including the level of education, open honesty, teamwork, and understanding of financial costs, were not incorporated into the final discussion. However, the item level of education proved to be necessary but not a must for senior executives, and the item open honesty is also one of the principles to be followed by staff in the workplace. Among the characteristics of senior executives, especially those responsible for organizational operations, most experts tend to ignore the integrity while emphasizing leaders' rigorous thinking mode under market competition. That means leaders will not easily let others figure out their thoughts. As the highest person in charge of products, division managers often compete with other business divisions within the organization, so they do not attach importance to teamwork. In addition, the understanding of financial costs only needs to show its concept rather than be highly valued, and the professional field is handled by professionals as support.

In ranking the assessment plans when appointing division managers, the following is true: the order of importance of the functional departments in the candidate rankings according to the preferred solutions are the business, production, administration, and R\&D departments.

\section{Conclusions and Suggestions}

\subsection{Conclusions}

Typically, the study of the organizational plan of a company is not performed in a static state. A company's organizational plan is essentially its lifecycle; the company adjusts its organization in response to the external environment, and as such, a more complicated market competition environment requires a more rigorous organization.

The appointment of a division manager tends to be part of the expansion and growth phase of a company's lifecycle. In this phase, the appointment of a division manager is a staffing matter requiring the company chairman's and president's attention. In Taiwan, many publicly listed companies began by splitting off from a parent company; therefore, division managers are appointed with more diligence than other staff managers. As the potential head of finance and accounting, administration, or procurement, division manager candidates are also assessed on multiple capabilities instead of a single expertise. In this study, a multiple criteria decision-making method was used to investigate the basic conditions for appointing division managers according to their functionality, management competencies, and traits.

This study is different from the previous research, which focus on the qualifications of predetermined candidates, because it shows the development process of selecting 
senior executives from a more professional perspective and pays attention to selecting the best from different candidates. Meanwhile, the structure established in this study not only displays the deficiencies in candidates' abilities but can be used as guidance for the organizations on training managers for leading different functional departments.

Faced with the topic of organizational management, most researchers are inclined to analyze through a qualitative method when there is research among the characteristics of potential senior executives, or the readiness and the qualifications of the successors. On the one hand, these studies tend to interview the individual cases of companies and summarize a consistent point of view as a reference for companies' training of senior executives. On the other hand, the discussion framework is more biased towards predetermined candidates as well as the practical experience provided by interviewees in the same field, which cannot avoid homogeneous thinking patterns in the same corporate environment. Therefore, fuzzy-set-based research methods can be viewed as a more appropriate way to incorporate expert opinions from various assessing sources. In sum, this study constructs a referral appointment of division managers and highlights its weights among the key factors, in order to provide a more specific reference for organizational development.

This study was based on fuzzy theories and involved multiple research processes and the use of TOPSIS to determine the order of solutions. This ranking demonstrated a preference for solutions prioritizing business managers for division manager. This also indicates that the company's attention to the markets in its operations, its product development, management comprehensiveness, product efficiency, and financial robustness are all major indicators of its operations. However, the business operator's considerations and the employees' expectations are obviously focused on maximizing the company product's market share to achieve sustainable operations. This leads to improved remuneration or job security for the employees, and to avoid losing market shares, which may lead to the company being acquired, lay-offs, or the closure of a division because of loss of business. This study indicates that for a division manager to effectively lead the team, the division manager must have a diverse range of capabilities, which is why business managers were ranked first in the criteria-based selection, followed by production managers. The practical verification also revealed that a renowned recruitment agency has the same views on the appointment of presidents as those demonstrated in this study; Chin [62], in his investigation, clearly stated that among the six types of business management-production management, sales and marketing management, human resources management, R\&D management, financial management, and information management-employees with backgrounds in sales and marketing or only marketing are the key to direct insight on the company's revenue because they are closer to the market. Relative to those in staff or R\&D departments, employees in line departments are more likely to qualify as corporate successors. This view is consistent with our conclusion, as drawn through multiple criteria research methods. Therefore, this study offers the following contributions:

1. A reference is provided for business operators or groups when appointing division managers;

2. Guidance is provided on the core curriculum for division managers;

3. Correlations are revealed between division manager competencies and other competencies;

4. The appointment of division managers is examined; and

5. Fuzzy multiple criteria research methods are applied to elucidate the mechanisms for appointing division managers.

\subsection{Suggestions}

The manager of a product division is key to the expansion of the company. However, for the division manager to accomplish their objectives, team formation is critical, as division managers must engage in teamwork with other staff to achieve the optimal results. Future scholars can consider focusing on functional departments within a division and using multiple criteria research methods to determine what organizational design and 
combination can improve operational efficiency, by examining various industry types or functional departments. Moreover, this study was based on publicly listed manufacturers in Taiwan. Whether the same correlations and importance as found in this study apply to other industries is a topic for further research.

Author Contributions: Conceptualization, M.-Y.L. and H.-L.C.; methodology, Y.-C.H. and H.-L.C.; software, H.-L.C.; validation, M.-Y.L. and H.-L.C.; formal analysis, H.-L.C. and Y.-C.H.; investigation, M.-Y.L. and H.-L.C.; writing—original draft preparation, M.-Y.L., H.-L.C., Y.-C.H.; writing—review and editing, M.-Y.L., H.-L.C.; supervision, M.-Y.L. and H.-L.C.; project administration, M.-Y.L. and H.-L.C. All authors have read and agreed to the published version of the manuscript.

Funding: This study received no external funding.

Institutional Review Board Statement: Not applicable.

Informed Consent Statement: Not applicable.

Data Availability Statement: Data is contained within the article.

Acknowledgments: The authors would like to thank the editor and the anonymous reviewers for their valuable comments.

Conflicts of Interest: The authors declare no conflict of interest.

\section{References}

1. $\quad$ Mintzberg, H. Structure in Fives: Designing Effective Organizations; Prentice-Hall, Inc.: Englewood Cliffs, NJ, USA, 1993.

2. Yin, Y.-C. A Political Economic Analysis of the Organizational Structure and Management Mode for Local Companies in Taiwan: A Case Study of Formosa Plastics Group and ASUSTek Computer Inc. Master of Business Administration Thesis, Soochow University, Taipei, Taiwan, 2011.

3. Chandler, A.D. Strategy and Structure: Chapters in the History of American Industrial Enterprises; MIT Press: Cambridge, MA, USA, 1962; p. 16.

4. Page, C.; Kolb, D.; Wilson, M.G. Management Competencies in New Zealand on the Inside Looking in Wellington; Ministry of Commerce: Wellington, New Zealand, 1994.

5. Ordonez-Ponce, E.; Clarke, A. Sustainability cross-sector partnerships: The strategic role of organizational structures. Corp. Soc. Responsib. Environ. Manag. 2020, 27, 2122-2134. [CrossRef]

6. Wen, C.-F. Organization Theory and Management; Hwa Tai Publishing: Taipei, Taiwan, 2009.

7. Mafimisebi, O.P.; Obembe, D.; Aluko, O. Organization and product design pairings: A review of product innovation capabilities, conceptualization, and future directions. Strateg. Chang. 2020, 29, 13-24. [CrossRef]

8. Kang, Y.-C. The Organization Design with Centralization and Decentralization. Master of Business Administration Thesis, National Cheng Kung University, Tainan, Taiwan, 2011.

9. Duncan, R. What is the right organization structure? Decision tree analysis provides the answer. Organ. Dyn. 1979, 7, 59-80. [CrossRef]

10. Seeds, D.; Khade, A.S. Transforming a multi-national corporation from a centralized organization to a decentralized organization. J. Int. Bus. Strategy 2008, 8, 99-104.

11. Hamel, G.; Prahalad, C.K. The core competence of the corporation. Harvard Bus. Rev. 1990, 68.

12. Daft, R.L. Organization Theory and Design, 12th ed.; Lee, T.Z., Translator; Hwa Tai Publishing: Taipei City, Taiwan, 2016.

13. Rothwell, W. Effective Succession Planning: Ensuring Leadership Continuity and Building Talent from Within; Amacom: New York, NY, USA, 2010.

14. Yang, M.M.; Young, S.; Li, S.J.; Huang, Y.Y. Using system dynamics to investigate how belief systems influence the process of organizational change. Syst. Res. Behav. Sci. 2017, 34, 94-108. [CrossRef]

15. Dai, S.-J. My Management Knowledge Center. 2019. Available online: https://mymkc.com/article/content/24177 (accessed on 12 January 2021).

16. Lessem, R. Total Quality Learning: Building a Learning Organization; Blackwell Publisher: Oxford, UK, $1992 ;$ p. 299.

17. Tu, S.-H. Study on the Succession Training Program for Mid-Level Executives in Family Businesses-Taking S Screw Company as an Example. EMBA Thesis, National University of Kaohsiung, Kaohsiung, Taiwan, 2010.

18. Barcus, S.W.; Wilkinson, J.W. Handbook of Management Consulting Services; McGraw-Hill: New York, NY, USA, 1986.

19. Ivancevich, J.M.; Szilagyi, A.D.; Wallace, M.J. Organizational Behavior and Performance; Goodyear: Santa Monica, CA, USA, 1977.

20. Hsiao, S.-Y. The Effect of Leader Personality and Leadership Style on Employee Job Performance: An Example of Textile and Chemical Fiber Industry. Ph.D. Thesis, Tunghai University, Taichung, Taiwan, 2015.

21. Guo, S.-C. Manager Today. 2019. Available online: https://www.managertoday.com.tw/columns/view/58074 (accessed on 18 April 2020). 
22. Drucker, P.F. Management: Tasks, Responsibilities, Practices; Commonwealth Magazine: Taipei City, Taiwan, 2020.

23. Bolton, A. Investing Against the Tide; Wu, K.-C., Translator; Locus Publishing Culture: Taipei, Taiwan, 2020.

24. Lee, Y.-P. The third westward wave: The success of Taiwanese businesses. Manag. Mag. 2007, 389, 28-34. Available online: http:/ / catalog.digitalarchives.tw/item/00/52/15/e1.html (accessed on 8 May 2020).

25. McClelland, D.C. Testing for competence rather than for "intelligence". Am. Psychol. 1973, 28, 1-14. [CrossRef] [PubMed]

26. Ulrich, D.; Brockbank, W.; Yeung, A. Human resource competencies in the 1990's: An empirical assessment. Pers. Adm. 1989, 34, 91-93.

27. Spencer, L.M.; Spencer, S.M. Competence at Work; Jhon Wiley \& Sons: New York, NY, USA, 1993.

28. Derouen, C.; Kleiner, B.H. New developments in employee training. Work Study 1994, 43, 13-16. [CrossRef]

29. Tsai, C.-C. TTQS Training Quality and Management Course. 2008. Available online: https://slidesplayer.com/slide/11110664/ (accessed on 15 September 2020).

30. Müller-Frommeyer, L.C.; Aymans, S.C.; Bargmann, C.; Kauffeld, S.; Herrmann, C. Introducing competency models as a tool for holistic competency development in learning factories: Challenges, example and future application. Procedia Manuf. 2017, 9, 307-314. [CrossRef]

31. Brinckmann, J. Competence of Top Management Teams and Success of New Technology-Based Firms; Gabler: Wiesbaden, Germany, 2008.

32. Chang, J.; Huang, T.-C. Exploration of management performance appraisal. Leadership Nurs. 2011, 12, 2-12.

33. Newland, C. Building the futures of local government politics and administration. In The Future of Local Government Politics and Administration; Washington, DC, USA, 2002; pp. 231-245.

34. Mintzberg, H. The Nature of Managerial Work; Haper \& Row: New York, NY, USA, 1973.

35. Hambrick, D.C.; Cho, T.S.; Chen, M. The influence of top management team heterogeneity on firms' competitive moves. Adm. Sci. Q. 1996, 41, 659-684. [CrossRef]

36. Garg, P.; Zhao, M. Knowledge sourcing by multidivisional firms. Strateg. Manag. J. 2018, 39, 3326-3354. [CrossRef]

37. McCall, M.W.; Hollenbeck, G.P. Developing Global Executives: The Lessons of International Experience; Harvard Business Press: Boston, MA, USA, 2002.

38. Wang, B.; Wei, S. Research on Competency Model of Top Management of Coal Enterprises. In Proceedings of the IOP Conference Series: Earth and Environmental Science, Bogor, West Java, Indonesia, 29 August 2019. [CrossRef]

39. Tsai, J.F.; Wang, C.P.; Chang, K.L.; Hu, Y.C. Selecting bloggers for hotels via an innovative mixed MCDM model. Mathematics 2021, 9, 1555. [CrossRef]

40. Boyatzis, R.E. The Competent Manager: A Model for Effective Performance; John Wiley \& Sons: New York, NY, USA, $1982 ;$ p. 308.

41. Bellman, R.E.; Zadeh, L.A. Decision-making in a fuzzy environment. Manag. Sci. 1970, 17, B-141. [CrossRef]

42. Chen, S.J.; Hwang, C.L. Fuzzy multiple attribute decision making methods. In Fuzzy Multiple Attribute Decision Making; Springer: Berlin/Heidelberg, Germany, 1992; pp. 289-486.

43. Zadeh, L.A. Information and control. Fuzzy Sets 1965, 8, 338-353.

44. Al-Najjar, B.; Alsyouf, I. Selecting the most efficient maintenance approach using fuzzy multiple criteria decision making. Int. J. Prod. Econ. 2003, 84, 85-100. [CrossRef]

45. Van Laarhoven, P.J.M.; Pedrycz, Y. A fuzzy extension of Satty's priority. Fuzzy Sets Syst. 1983, 11, 229-241. [CrossRef]

46. Kaufman, A.; Gupta, M.M. Introduction to Fuzzy Arithmetic; Van Nostrand Reinhold Company: New York, NY, USA, 1991.

47. Zimmerman, H.J. Fuzzy Set Theory and Its Applications, 2nd ed.; Kluwer Academic Publishers: Boston, MA, USA, 1991.

48. Chang, S.S. Fuzzy Multi-Criteria Evaluation Method and Statistics; Wu-Nan Book Inc.: Taipei, Taiwan, 2012.

49. Hu, Y.-C.; Hsiao, Y.-C. Key factors of pricing in technology transfer: A case study of domestic sputtering targets. J. Manag. Syst. 2012, 19, 527-560.

50. Murray, T.J.; Pipino, L.L.; Van Gigch, J.P. A pilot study of fuzzy set modification of Delphi. Hum. Syst. Manag. 1985, 5, 76-80. [CrossRef]

51. Klir, G.J.; Folger, T.A. Fuzzy Sets, Uncertainty, and Information; Prentice Hall: Binghamton, NY, USA, 1988.

52. Ishikawa, A.; Amagasa, M.; Shiga, T.; Tomizawa, G.; Tatsuta, R.; Mieno, H. The max-min Delphi method and fuzzy Delphi method via fuzzy integration. Fuzzy Sets Syst. 1993, 55, 241-253. [CrossRef]

53. Hsu, T.-H. Fuzzy Delphi analytical hierarchy process. J. Chin. Fuzzy Syst. Assoc. 1998, 4, 59-72.

54. Huang, L.C.; Hsieh, S.Y.; Chang, P.T. A comparison of fuzzy Delphi methods with an application to assessment factor selection for bank employees. J. Chin. Inst. Ind. Eng. 2001, 18, 1-13. [CrossRef]

55. Tzeng, G.H.; Teng, J.Y. Transportation investment project selection with fuzzy multiobjectives. Transp. Plan. Technol. 1993, 17, 91-112. [CrossRef]

56. Lin, C.J.; Wu, W.W. A causal analytical method for group decision-making under fuzzy environment. Expert Syst. Appl. 2008, 34, 205-213. [CrossRef]

57. Li, R.J. Fuzzy method in group decision making. Comput. Math.Appl. 1999, 38, 91-101. [CrossRef]

58. Tamura, H.; Akazawa, K. Structural modeling and systems analysis of uneasy factors for realizing safe, secure and reliable society. J. Telecommun. Inf. Technol. 2005, 3, 64-72.

59. Hu, Y.C.; Chiu, Y.J.; Hsu, C.S.; Chang, Y.Y. Identifying key factors for introducing GPS-based fleet management systems to the logistics industry. Math. Probl. Eng. 2015, 2015. [CrossRef] 
60. Hwang, C.L.; Yoon, K. Multiple Attribute Decision Making Methods and Applications, a State of the Art Survey; Springer: New York, NY, USA, 1981.

61. Buckley, J.J. Ranking alternatives using fuzzy numbers. Fuzzy Sets Syst. 1985, 15, 21-31. [CrossRef]

62. Chin, J. 104 Job Bank Investigation Report. 2020. Available online: https:/ / www.setn.com/News.aspx?NewsID=762727 (accessed on 5 April 2021). 